\title{
Influence of Immigration Policies on Supply of Ethnic Business Entrepreneurs in Canada
}

Shuguang Wang \& Rebecca Hii RCIS Working Paper No. 2019/1 March 2019

\section{SERIES EDITOR Usha George}

Ryerson Centre for Immigration \& Settlement Ryerson University Jorgenson Hall, 627 350 Victoria Street, Toronto, ON M5B2K3 http://www.ryerson.ca/rcis 
No. $2019 / 1$

\title{
Influence of immigration Policies on Supply of Ethnic Business Entrepreneurs in Canada
}

\author{
Shuguang Wang \\ Department of Geography and Environmental Studies, Ryerson University \\ Rebecca Hii \\ Ph.D. Program in Policy Studies, Ryerson University
}

Series Editor: Usha George

RCIS Working Papers present scholarly research of all disciplines on issues related to immigration and settlement. The purpose is to stimulate discussion and collect feedback. The views expressed by the author(s) do not necessarily reflect those of RCIS. For a complete list of RCIS publications, visit www.ryerson.ca/rcis

ISSN: 1929-9915

(c) (i) $\ominus$ Creative Commons Attribution-Noncommercial-No Derivative Works 2.5

EY NC ND Canada License 


\begin{abstract}
Traditional theories deal with ethnic business mainly from the perspectives of structural opportunities and ethnic group characteristics. While they explain very well why some ethnic groups have higher rates of business formation and ownership than others, much less attention has been paid to the role of government policies in regulating the inflow of business immigrants and channelling ethnic entrepreneurs and related resources into different business sectors. Using Canada as a case study, this paper examines how changes in immigration policies have influenced business immigrant flows and ethnic business development (since most ethnic businesses are initiated and run by immigrants). This study found that the recent changes in Canada's immigration programs have resulted in substantial decrease in the inflow of business immigrants, and may turn many resourceful business immigrants to the competing countries of the U.S., Australia and the UK, which all have more affordable and less restrictive investment requirements. The paper suggests that future studies of ethnic business should be expanded to include immigration policies as an explicit facilitating or restricting factor.
\end{abstract}

Keywords: immigration policy; business immigrants; ethnic business; Canadian immigration 


\section{Table of Contents}

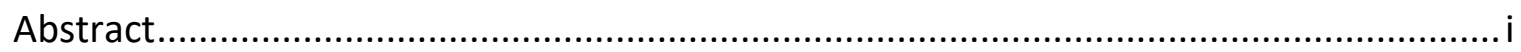

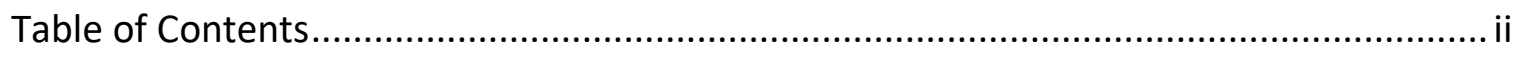

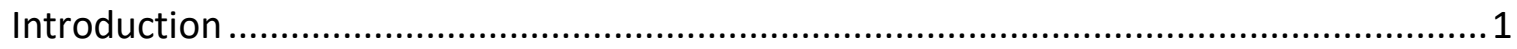

A Synopsis of Immigration Policy Theories ....................................................................... 2

The Evolution of Canadian Business Immigration Programs since 1978 ...........................4

The 1978 Entrepreneur and Self-Employed Immigrant Programs, and the 1986 Investor

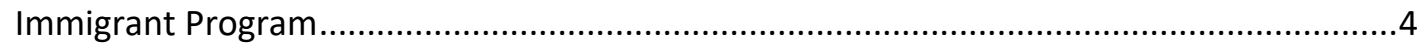

Provincial Business Immigrant Programs and Streams .....................................................6

Start-Up Visa Program and Investor Venture Capital Program ..........................................

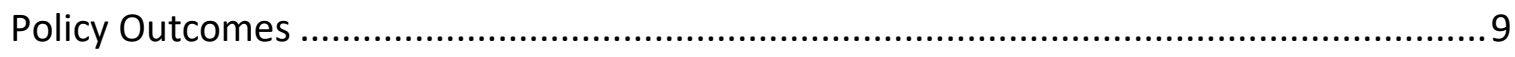

Implications for Future Development of Ethnic Business in Canada ............................15

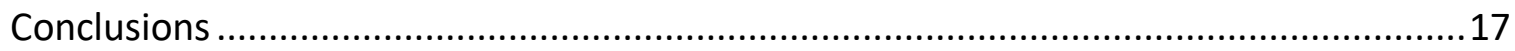

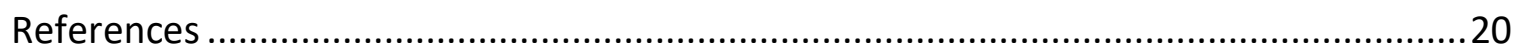




\section{Introduction}

Ethnic business refers to commercial enterprises that are owned and operated by members of an ethnic group, and that offer culturally specific and suitable goods to serve the co-ethics of the business owners. The history of ethnic business is almost as long as the history of immigration of minorities in the immigrant-receiving countries. In recent decades, ethnic businesses have both proliferated and diversified. Accordingly, progressive theorization has been made by more than one generation of scholars to advance our understanding of the meanings of ethnic economy and entrepreneurship. However, most existing theories (such as Blocked Mobility, Cultural Resources, Enclave Economy, and Interactive Model of Entrepreneurship) deal with ethnic business from the perspectives of labour market discrimination, opportunity structure, and ethnic group characteristics. These theories assume (implicitly) that the ethnic entrepreneurs are already in the "country of immigration", and aim to explain why some ethnic groups have higher rates of business formation and ownership than others, thus leading to the development of ethnic economies with high levels of institutional completeness. Yet, they are inadequate to explain where the entrepreneurs and their business capital come from, and much less attention has been paid to the role of government policies in recruiting and channelling immigrant entrepreneurs and related resources into ethnic businesses.

The more recent theory of Mixed Embeddedness advances the study of ethnic entrepreneurship one step further by linking opportunity structure - the pivotal concept in the Interactive Model of Entrepreneurship - with the supply side of the entrepreneurial market (Kloosterman, van der Leun and Rath, 1999; Kloosterman, 2006). Adopting a political economy perspective, the Mixed Embeddedness thesis unpacks the notion of opportunity structure by looking at the way different opportunity structures are institutionally embedded, and argues that immigration policy influences (or interferes) opportunity structure (Kloosterman, 2006). For example, in addition to the existence of a sufficient demand for a certain bundle of ethnic products, the (contemporary) aspiring entrepreneurs must have the right kind of resources, including financial, human and social capitals. Invariably, business immigrant policies aim to select business immigrants who possess the required level of financial and human capital to start a particular business, but exclude those who do not. Business immigration policy adjustments in response to changes in the nation's economic conditions often also influence opportunity structures. Conceptually, the mixed embeddedness framework explicitly links the micro-level economic actors (the immigrant entrepreneurs) with the meso-level economic environment (the opportunity structure), and links the meso-level economic environment with the macro-level institutional ecosystem (consisting of institutional forces, regulations, and immigration policies), pointing to the importance of including immigration policies in the study of ethnic entrepreneurship.

In Canada, as in many other immigrant-receiving countries, development of ethnic businesses is closely related to immigration, and most ethnic businesses are initiated and run by immigrants. In the past, most immigrants came to Canada as labourers. Some became toiling shopkeepers and restaurateurs due to their inability to find paid employment in the host society (as explained by the Blocked Mobility thesis). In the recent decades, many immigrants moved to Canada with the intention and a well-conceived plan to run a business in their chosen destination. As the Canadian economy shifts deeper into the post-industrial expansive phase, Canada needs more immigrant entrepreneurs who can participate and contribute to businesses of highly capital-intensive, mass production, as reflected in its recent business immigration policies. Therefore, the post-industrial employment trajectories influence immigration policies, and immigration policy changes affect both the number of immigrant entrepreneurs and the composition of the immigrant entrepreneur population (Kloosterman, 2006). 
This paper examines how changes in immigration policies over the last four decades in Canada have influenced the supply of ethnic entrepreneurs and business capital. The main body of this paper consists of four parts. The first part is a synopsis of immigration policy theories, from which a theoretical framework is highlighted to inform the current study. In the second part, major policy initiatives and changes, along with the associated controversies and criticism, are reviewed. In the third part, we examine the impacts of the program changes (or policy outcomes) on business immigrant flows. The fourth part discusses the implications for future development of ethnic businesses in Canada. The paper concludes that explanation for ethnic business development needs to go beyond the existing theories and be expanded to include immigration policy as an important facilitating (or intervening) factor for opportunity structures.

\section{A Synopsis of Immigration Policy Theories}

Immigration studies fall into two broad areas of research: (1) immigration policies and politics, and (2) immigration policy outcomes and impacts. Immigration policies are designed to control, as well as facilitate, population movement across national borders. In general, immigration policies are concerned with three main matters: the number, type, and country of origin. The formulation of immigration policies, which take the form of laws and ministerial regulations, is guided by various policy theories, either consciously or unconsciously. Theoretical approaches dealing with immigration policies attempt to explain what shape a country's immigration policies.

Immigration policy is multidimensional. For example, in its official statement, Canada's immigration programs have four objectives (Seward, 1987): demographic, economic, social, and humanitarian, though in practice, economic consequences have always been the driving force of debate on Canadian immigration policies (Wang and Lo, 2000). This means that immigration policies are differentiated not only by the type of immigrants to be admitted but also by the types of instrument, or different types of visa and program (Milner and Tingley, 2011). Accordingly, there is a wide range of theoretical approaches that can be used to examine immigration policies (Zogata-Kusz, 2012).

At a high level, Milner and Tingley (2011) distinguish two sets of theories: economic models, which are based on both labour market theories and fiscal theories, and ideology, which explains non-economic sources of political support for, or opposition to, immigration. Labour market theories explain immigration policies from the viewpoint of need to increase labour who contribute to the national and local economy; whereas fiscal theories explain the aspects of immigration policies for need to minimize redistribution of tax and welfare allocated to subsidize new immigrants. An extensive literature has examined the effect of immigration policies on economic outcomes. As for the influence of ideologies, Milner and Tingley (2011) distinguish between conservative ideology and liberal ideology. Existing evidence suggests that conservatives are less likely to support immigration than the liberals, as they are concerned with the high (perceived or real) cost of settling newcomers. In contrast, liberals may favor less restrictive immigration policies, such as higher immigration quota and less border control, and are more in favor of making employers bear the burden of immigration control. Relating to ideology, the conservatives often take a utilitarian approach in immigration policy making, with a focus on economic consequences, while the liberals tend to take a "cosmopolitan calculus" approach, weighing the welfare of each individual - both citizen and prospective immigrant - equally (Macklin, 2010).

Alternatively, Zogata-Kusz (2012) generalizes seven theoretical perspectives (i.e., 
considerations or influences) in immigration policy making. ${ }^{1}$ In a simplistic division, the author separates them into two broad approaches: actor-based approach and factorbased approach.

Actor-based approach focuses on immigration policy making and explains immigration politics with the activities of state institutions and bureaucracy, domestic politics (involving various interest groups including ethnic groups, NGOs, labor unions, and employers), theories of globalization, and international institutions (such as the Office of the UN High Commissioner for Refugees). As for the importance of domestic politics, Freeman (1995) argued that immigration policy-making in democracies follows the pattern of 'client politics', because the costs of immigration are diffused among the entire electorate, while benefits are concentrated within a small pool of employers. Furthermore, the classical political economy approach, one of the actor-based approaches, analyzes different actors' interests (cost and benefit) to determine which problems are set on the agenda with priority and how compromises are made and decisions taken (Natter, 2018).

Factor-based approach concentrates on such factors as economic interest, national identity, national security, globalization, foreign policy reflections, and human rights. In the $21^{\text {st }}$ century, the consideration of national identity has become much less important than before in immigration policy making, but the influence of globalization and foreign policy reflections have become more prominent. Nowadays, the shaping of immigration policies depends much less on cultural and linguistic similarities between the sending and receiving countries. Instead, the need to attract global talents and capital, and obligations to resettle refugees, have had more influence on immigration policy making. The theorists of globalization also claim that the power of states to create immigration policy autonomously is now limited by the pressure of international organizations and institutions (Zogata-Kusz, 2012).

In yet another classification, Natter (2018) distinguishes between "issues-specific" theories and "regime-specific" theories. The former capture immigration policy processes regardless of the political system in which policy makers (i.e., actors) function, while the latter are tied to the characteristics of the political system where decisions are made. This distinction is particularly useful for the study of immigration legislation and programs in two ways: (1) for comparisons between democratic states and authoritarian regimes; and (2) for contrasting between conservative and liberal ideologies, often held by different governing parties in the same country.

In sum, immigration policies are multifaceted, and immigration policy making is shaped by interactions of multiple actors and in consideration of many factors. As most theorists agree, none of the theories reviewed in this synopsis can provide a freestanding account of immigration policy, and most studies combine different theoretical aspects to explain observed policy formulation and changes. The current study presented in this paper is informed by both economic theories and ideology of the governing party.

\footnotetext{
1 These seven perspectives are: (1) state institutions and bureaucracy; (2) domestic politics; (3) theories of globalization and international institution; (4) economic interests and the state of the economy; (5) national identity; (6) human rights; (5) foreign policy reflections.
} 


\section{The Evolution of Canadian Business Immigration Programs since 1978}

The contemporary business immigrant programs in Canada began in 1978. Since then, a series of program expansion and revisions have been introduced and implemented to address the problems of the programs, and in response to the changing economic conditions of the country. These include the Entrepreneur and Self-Employed Immigrant Programs (1978), the Investor Immigrant Program (1986), the Provincial Nominee Program (1998), the Start-Up Entrepreneurs Program (2013), and the Immigration Investor Venture Capital Pilot Program (2015).

\section{The 1978 Entrepreneur and Self-Employed Immigrant Programs, and the 1986 Investor Immigrant Program}

In 1978, the federal government, for the first time, introduced two new immigration categories under the Independent Immigrant class: entrepreneur, and self-employed, immigrants (CIC, 2014a; Knowles, 2016; Li, 2003).

The objective of the Entrepreneur program was to select immigrants with business experiences who would own a business and manage it in Canada, and create jobs for other Canadians (CIC, 2014a; CIC, 2014c). Entrepreneur immigrants were expected to meet certain terms and conditions within three years of landing to satisfy their permanent residency status. First, they had to control at least one-third of a business in Canada and assume an active management role in the business. Second, they needed to create a minimum of one full-time job for Canadian residents (CIC, 2015). The objective of the Self Employed Immigrant program was to select immigrants who would create their own employment either in farm management or in a field that would enable them to contribute to the cultural or athletic life in Canada (CIC, 2014d; IRCC, 2017b).

Initially, the entrepreneur and self-employed classes of immigrants were not accorded high priority in application processing due to the economic recession in the late 1970 s and the early 1980s. The federal government instead focused on processing applications in the Family and Refugee classes and the independent immigrants with prearranged employment (Green and Green 2004; Wong, 1993). It was not until 1984, after the decade-long recession, when business class applicants were given higher processing priority ahead of family and refugee classes (Knowles, 2016).

In 1986, the federal government created another new category of business immigrants, known as the Investor Immigrant class. The creation of the investor category was to attract financial capital to stimulate job creation and economic growth in Canada (Wong, 1993). Investor immigrants were expected to possess high personal net worth and business experience and provide a minimum five-year, interest-free investment to the federal government, which would distribute the funds to economic development projects across the country (CIC, 2014a; CIC, 2014e).

Initially, the Investor class immigrants were required to possess a net worth of $\$ 500,000$ and invest a minimum of $\$ 250,000$ in Canada (DeRosa, 1995). Over time, the threshold was raised twice. From 1999 to 2010, investor immigrants were required to possess a net worth of $\$ 800,000$ and make a minimum investment of $\$ 400,000$. Between 2010 and 2014, the threshold was doubled with applicants being required to possess a net worth of $\$ 1.6$ million and deliver a minimum investment of $\$ 800,000$ (CIC, 2010; GOC, 2014). Until 2014, the investment was basically a loan to the Canadian government for five years; after that, the principal was returned to the investor without interest.

The Investor Immigrant program became the fastest-growing business category in Canada, ahead of the entrepreneur and self-employed categories (Knowles, 2016). Its focus on international investors appeared to attract wealthy immigrants as a ready source 
of capital and potential trade links to world markets (Green and Green, 2004; Li, 2003). Both the Entrepreneur and Investor programs were particularly popular among immigrants from Hong Kong. Some commentators suggested that the introduction of the Investor immigrant program was a purposeful move by the federal government to respond to the exodus of investors and entrepreneurs from Hong Kong at that time, who were concerned about the uncertainties surrounding the handover of Hong Kong to China in 1997 and were considering Canada as a safe haven for capital investment (Li, 1993 and 2005; Wang, 1999)

The business immigrations programs have been surrounded with controversies. Charles Campbell, former vice-chairman of the Immigration Appeal Board, noted in his book, Betrayal and Deceit, that major failures of the Entrepreneur Program began to occur in the early years of its introduction (Murray, 2005). When entrepreneurs were not able to employ five people, the requirement lowered to two jobs; and when that didn't work, the requirement was reduced to one job. In the new millennium, the Entrepreneur Immigrant Program was considered inadequate in meeting the needs of Canada's post-industrial economic growth, as it was no longer bringing in the "in-demand" entrepreneurs. The entrepreneurs, brought in under the existing program, did not create many jobs, and most jobs created by them were low skilled and low paid. In other words, they did not contribute to Canada's innovation and competitiveness in the global economy (Reitz, 2004). The current economic conditions in Canada require a new generation of entrepreneurs who are familiar with the growing foreign markets and the associated regulations and customs. It is no longer sufficient for an entrepreneur immigrant to be only able to open a shop or restaurant.

Despite the popularity of the Investor Immigrant category, the program was riddled with controversy almost from its beginning. Instances of fund mismanagement, insufficient program monitoring by the federal and provincial governments, and misrepresentation of program marketing were reported in Alberta and Manitoba in the early 1990s. These practices ultimately resulted in cases of investors losing their investments, embezzlement by fund managers, and economic benefits not going to the intended province. A temporary program moratorium was put into place in 1994 and revisions were made shortly after, to prevent further program abuse. These revisions included restricting passive investments in real estate and stricter monetary fines for unscrupulous fund managers (DeRosa, 1995: 386).

Controversies surrounding both the Investor and Entrepreneur programs were not limited to instances of mismanagement. While business class immigrants were assessed using the same Points System as were other economic class immigrants, they were subjected to substantially lower point thresholds, with selection focusing primarily on their personal net worth and business experience. As a result, it was possible for Investor and Entrepreneur immigrants to be selected for entry to Canada with lower official language fluency or education qualifications than other economic class immigrants (Harrison, 1996; Ley, 2003). It was for this reason that critics panned the program for essentially enabling the wealthy to fast-track their way into Canada, making them a privileged class of immigrants over the other applicants.

Questions also circulated regarding the actual benefits of the Entrepreneur and Investor Immigrant programs for the Canadian economy - the policy outcomes. Evaluations of the federal Entrepreneur and Investor programs by Citizenship and Immigration Canada $(\mathrm{CIC})$ found that while these business immigrants were relatively low users of social assistance and employment insurance (EI) benefit, they paid substantially less personal income tax than other economic immigrants (particularly skilled workers). Investor and Entrepreneur immigrants were also more likely to settle in the popular destination provinces of Ontario and British Columbia; other provinces were not benefiting from the business activities of these newcomers in their fair share (CIC, 2014a). The CIC 
evaluations also discovered insufficient monitoring of the Entrepreneur program to ensure that the entrepreneur immigrants were indeed meeting the terms and conditions of the program. In the 2014 Economic Action Plan and the 2014 CIC Annual Report, the Investor Immigrant program was even described as undervaluing Canadian permanent residence, and having the propensity to attract "astronauts", who would move their families to Canada but continue to conduct their business abroad, eluding Canadian tax authorities (GOC, 2014; CIC, 2014b; 2014c; Carmen and O'Neil, 2014). More importantly, it was found that the Investor and Entrepreneur programs were not aligned to the federal government's new priorities to promote greater innovation in the Canadian economy, because most of the immigrant businesses concentrate in small-scale and low-tech commercial activities (IRCC, 2016). The federal government, led by the Progressive Conservative Party (PCP), first suspended the Investor program in 2012, and subsequently, with the passing of Bill C-31, terminated both of the Investor and Entrepreneur Immigrant programs in 2014.

\section{Provincial Business Immigrant Programs and Streams}

In Canada, immigration is largely the responsibility of the federal government. However, certain powers of immigration have been decentralized to provincial governments. The Province of Quebec, with a high level of autonomy as prescribed in the Canadian Constitution, has been managing its own immigration affairs for a long time. Specifically, Quebec has been running its own parallel investor program since 1986. Under the Quebec model, investments are secured by the provincial government and managed by Investissement Quebec, a Quebec government agency. Only after a governmentapproved third-party financial institution has vetted all documentations for program compliance, does the agency then allocate the applicant's investment to qualified Quebec businesses. The Quebec program, which was not affected by the cancellation of the federal programs, is said to be fraud free. However, the two former immigration ministers, Chris Alexander and Jason Kenney, both complained that a majority of the Quebec applicants who paid their fees and invested their money in Quebec ended up living in Ontario and British Columbia, and using the social services funded by taxpayers of these two provinces (Carmen and O'Neil, 2014).

In 1998, the Provincial Nominee Programs (PNPs) were established to allow other provinces and territories to select certain immigrants according to their local labor market needs. As part of the PNPs, most provinces and Territories included categories of business immigrants (see Table 1). However, unlike Quebec, the other provinces and Territories can only nominate applicants, but the power of approval remains in the hands of the federal government. This is a major difference between the Quebec program and the PNPs. The provincial programs have not been fraud free either. Various problems were reported for the provinces of Manitoba, Nova Scotia, P.E.I. (Pagtakhan, 2012) and Yukon (Immigration.ca, 2017). Three Atlantic provinces had to close their business immigration programs at various points in time (Pagtakhan, 2012). In 2018, P.E.I. closed permanently both the $100 \%$ Ownership and Partial Ownership business immigration stream of its Provincial Nominee Program (Yarr, 2018). 
Table 1 Provincial Business Immigration Programs/Streams in Canada

\begin{tabular}{|c|c|}
\hline & Program \\
\hline \multirow{3}{*}{ Quebec } & $\begin{array}{l}\text { Quebec Immigrant Investor Program - Individuals who can demonstrate } \\
\text { an advanced intermediate level of French are exempt from the quota. }\end{array}$ \\
\hline & $\begin{array}{l}\text { Quebec Entrepreneur - Capped out (individuals who can demonstrate } \\
\text { an advanced intermediate level of French may continue to apply) }\end{array}$ \\
\hline & Quebec Self-Employed Worker Program - Capped out \\
\hline Alberta & Alberta Self-Employed Farmer Stream \\
\hline B.C. & $\begin{array}{l}\text { British Columbia Provincial Nominee Program (BC PNP) - Entrepreneur } \\
\text { Stream }\end{array}$ \\
\hline Manitoba & Manitoba Provincial Nominee Program for Business (MPNP-B) \\
\hline New Brunswick & $\begin{array}{l}\text { New Brunswick Provincial Nominee Program (NBPNP) - Business } \\
\text { Applicants (suspended) }\end{array}$ \\
\hline \multirow{2}{*}{ Nova Scotia } & Nova Scotia Nominee Program (NSNP) - Entrepreneur Stream \\
\hline & $\begin{array}{l}\text { Nova Scotia Nominee Program (NSNP) - International Graduate } \\
\text { Entrepreneur Stream }\end{array}$ \\
\hline Northwest Territory & $\begin{array}{l}\text { Northwest Territories Nominee Program (NTNP) - Entrepreneur } \\
\text { Business }\end{array}$ \\
\hline \multirow{2}{*}{ Ontario } & Ontario Immigrant Nominee Program (OINP) - Corporate Stream \\
\hline & Ontario Immigrant Nominee Program (OINP) - Entrepreneur Stream \\
\hline \multirow{2}{*}{ PEI } & $\begin{array}{l}\text { Prince Edward Island Provincial Nominee Program (PEI-PNP) - 100\% } \\
\text { Ownership (cancelled in 2018) }\end{array}$ \\
\hline & $\begin{array}{l}\text { Prince Edward Island Provincial Nominee Program (PEI-PNP) - Partial } \\
\text { Ownership (cancelled in 2018) }\end{array}$ \\
\hline \multirow{2}{*}{ Saskatchewan } & $\begin{array}{l}\text { Saskatchewan Immigrant Nominee Program (SINP) - Entrepreneur } \\
\text { Category }\end{array}$ \\
\hline & $\begin{array}{l}\text { Saskatchewan Immigrant Nominee Program (SINP) - Farm } \\
\text { Owner/Operator Category }\end{array}$ \\
\hline Yukon & Yukon Business Nominee Program (YBNP) \\
\hline
\end{tabular}

Source: CanadaVisa http://www.canadavisa.com/canadian-business-immigration-table.html; Yarr, 2018 


\section{Start-Up Visa Program and Investor Venture Capital Program}

Under the PCP government, amendments were made to the Immigration and Refugee Protection Act (IRPA) in 2008 that bestowed the Minister of Citizenship and Immigration the authority to issue special Ministerial Instructions relating to a variety of economic immigration issues (CIC, 2011; IRCC, 2017a). In relation to the business class programs, Ministerial Instructions were issued consecutively in 2010, 2011 and 2012, first to temporarily pause accepting new Investor Immigrant applications, and then place a moratorium on the acceptance of Entrepreneur class applications.

The Ministerial Instructions played an important role in the changes in immigration policy post-2008. Section 14.1 of IRPA allows the Minister to issue special instructions to create temporary (less than five years duration) economic immigration programs (IRCC, 2017a), effectively resulting in the creation of the Immigrant Start-Up Visa and Immigrant Investor Venture Capital Class programs.

The Immigrant Start-Up Visa program was introduced in April 2013 in response to one of the Government of Canada's priorities to actively boost the Canadian economy through greater innovation. It is designed to attract a new type of foreign entrepreneurs from around the world, who can contribute innovative ideas and actively pursue innovative business ventures that are productive, create better jobs, and can compete globally (CIC, 2014c). Three business organizations are invited for partnership: (1) Venture Capital and Private Equity Association; (2) National Angel Capital Organization; and (3) Canadian Association of Business Incubators. Start-Up Visa applicants first must seek a designated Canadian venture capital fund or angel investor group, as well as a business incubator, who will review and vest their business plans, and agree to provide mentorship for their business plan execution. Second, each applicant must also secure a minimum investment of $\$ 200,000$ if sponsored by a venture capital or private equity fund, or $\$ 75,000$ if sponsored by an angel capital fund.

Unlike the previous federal Entrepreneur program, the Start-Up Visa program requires that applicants possess a higher level of Canadian language proficiency (i.e., Canadian Benchmark Level 5) and must prove that they have sufficient funds to live independently in Canada. The program initially also included a minimum educational requirement with at least one year of the equivalent of Canadian post-secondary education, but that requirement was later removed through another Ministerial Instruction (CIC, 2014a), so that the next Bill Gates or Steve Jobs, who were both university dropouts, would not be left out.

Following the discontinuation of the Immigrant Investor program, the same PCP federal government introduced the Immigrant Investor Venture Capital (IIVC) program in January 2015. This was a one-year pilot program, aiming to select up to 60 immigrant investors who had a personal net worth of $\$ 10$ million and were prepared to invest a minimum of $\$ 2$ million (up from $\$ 800,000$ ) into the Immigrant Investor Venture Capital fund, managed by BDC Capital (the investment arm of the Federal Business Development Bank of Canada) and intended to assist in financing promising Canadian entrepreneurs and start-ups (including immigrant start-ups). In essence, the foreign capital brought in by the immigrant investors will be used to nurture innovation-based Canadian companies (headquartered outside the Province of Quebec) to create high-quality jobs and compete in the world economy, while reducing risks and liabilities for the Canadian tax payers. Whereas the previous Investor Immigrant program required the participating immigrants to maintain their investments for a period of 5 years, the Venture Capital immigrants must keep their investments in the IIVC fund for 15 years (CIC, 2015; IRCC, 2016; IRCC, 2017b). Also, there is no guarantee for the principal, meaning that the investment will be fully at-risk. Proceeds from the IIVC fund, including interest and capital gains, if any, may be distributed to the immigrant investors periodically, depending on the performance of 
the fund. Any remaining fund assets could also be distributed among immigrant investors at the end of the investment term.

Furthermore, the net worth of $\$ 10$ million must have been acquired through lawful profit-making businesses or investment activities. Personal net worth acquired through inheritance or in the value of primary residence does not count, as these are not considered "business or investment activities" for the purpose of this program. Applicants of the IIVC program must also meet minimum official language requirements (Canadian Benchmark Level 5) as well as minimum educational qualifications equivalent to one year of Canadian post-secondary education. Those who do not meet the educational requirements must possess an even higher net worth of $\$ 50$ million. The purpose of including official language and educational requirements is to select immigrants who can more easily adapt and integrate into the Canadian economy and society (CIC, 2015; IRCC, 2017b), because as passive investors, these immigrants are not likely to be working in the business of their own investment.

Clearly, both the Immigrant Start-Up Visa and Immigrant Investor Venture Capital programs aim to attract business immigrants who can better fulfil Canada's current economic needs and priorities, with a particular focus on innovation. They also aim to attract business immigrants with higher levels of human capital, in particular those with higher English or French language proficiency and those with higher educational attainment. The Start-Up Visa program also requires the active involvement of entrepreneurs, and the support of a designated business entity (a venture capital fund or an angel capital organization, as well as a business incubator) to potentially ensure success of the business venture.

The two new business programs have resulted in changes in human capital characteristics of the business immigrants. According to a recent federal evaluation, it was found that the Start-Up Visa immigrants, when compared to federal Entrepreneur immigrants, have higher rates of post-secondary education completion, greater knowledge of English or French, and higher proportions who are willing to settle in the Atlantic provinces, which have historically faced challenges in attracting new immigrants (IRCC, 2016).

The two new programs have not escaped criticism, however. One of the critiques of the Start-Up Visa program is the relatively low volume of immigrants that applied and were accepted to the program when compared to the former federal Entrepreneur Program (IRCC, 2016). Furthermore, as of 2016, one year after the launch of the Investor Venture Capital program, only 7 applications were received and no permanent resident visas were issued (Mas, 2016), meaning that the pilot program did not achieved its prescribed goal.

\section{Policy Outcomes}

Business immigrants account for a small proportion of all immigrants to Canada: only 6.2 percent of the total in the last 36 years (1980-2016). However, they are accepted, and even recruited proactively, for different purposes, as described in the preceding section.

According to the Canadian immigration landing data, Canada admitted close to half a million business immigrants $(484,440)$ in the 36 years 1980-2016 (see Table 2). Of these business immigrants, 42 percent were entrepreneurs, 16 percent were selfemployed, and 42 percent were investors. If they had all fulfilled their immigration requirements as prescribed in the business immigrant programs, they would have established 280,000 (small) businesses and created at least the same number of jobs (by the entrepreneurs and the self-employed), and brought in 93 billion dollars of investment 
(by the investors) to Canada. ${ }^{2}$

Table 2 Summary of Business Immigrants* to Canada by Period of Time

\begin{tabular}{|c|c|c|c|c|}
\hline Period & Entrepreneur & Self-employed & Investor & $\begin{array}{c}\text { Total business } \\
\text { immigrants }\end{array}$ \\
\hline $1980-1999$ & 167,725 & 61,124 & 71,655 & 300,504 \\
& $(55.8 \%)$ & $(20.3 \%)$ & $(23.8 \%)$ & $(100 \%)$ \\
\hline $2000-2016$ & 37,221 & 16,096 & 130,619 & 183,936 \\
& $(20.2 \%)$ & $(8.8 \%)$ & $(71.0 \%)$ & $(100 \%)$ \\
\hline & & & & \\
\hline $1980-2016$ & 204,946 & 77,220 & 202,274 & 484,440 \\
& $(42.3 \%)$ & $(15.9 \%)$ & $(41.8 \%)$ & $(100 \%)$ \\
\hline
\end{tabular}

Source: Immigration, Refugee and Citizenship Canada (IRCC), 2014 and 2017c

*Principal applicants only

Business immigrant flows and composition exhibit notable temporal patterns, coinciding with the major program changes. In the early years of the business immigration programs (before 1984), Canada admitted more self-employed immigrants than entrepreneurs (see Figure 1). After 1984, the number of self-employed immigrants declined, and the number of entrepreneurs increased significantly and peaked in 1992, with 16,000 accepted in that year. After the peak year, however, the number of entrepreneurs declined precipitously - to merely 150 in 2016. In accordance with the introduction of the Investor Immigrant program, investors began to arrive in Canada in 1986, and their number increased continuously for six years, and also peaked in 1992. After a 10-year period of decline, the investor immigrant category resumed to increase from 2003 to 2010, but declined again when the effectiveness of the Investor Immigrant Program was called into serious question by the PCP federal government. Nonetheless, the investor immigrants remained to be the largest class of business immigrants, exceeding both entrepreneurs and self-employed, with those who landed in Canada after 2014 all having applied before the program was terminated. The changes in the composition of the business immigrants are more clearly summarized in Table 2 . Between 1980 and 1999, 56 percent of all the business immigrants were entrepreneurs; only 24 percent were investors. In the new millennium (2000-2016), the proportion of entrepreneurs went down to 20 percent; while the proportion of investors jumped to 71 percent.

2 The estimation is made assuming that each investor who landed between 1980 and 1998 brought in $\$ 250,000$; those landed between 1999 and 2009 each brought in $\$ 400,000$; and those landed between 2010 and 2016 each brought $\$ 800,000$. 
Figure 1 Inflow of Business Immigrants to Canada, 1980-2016 (with year of business immigrant program introduction)

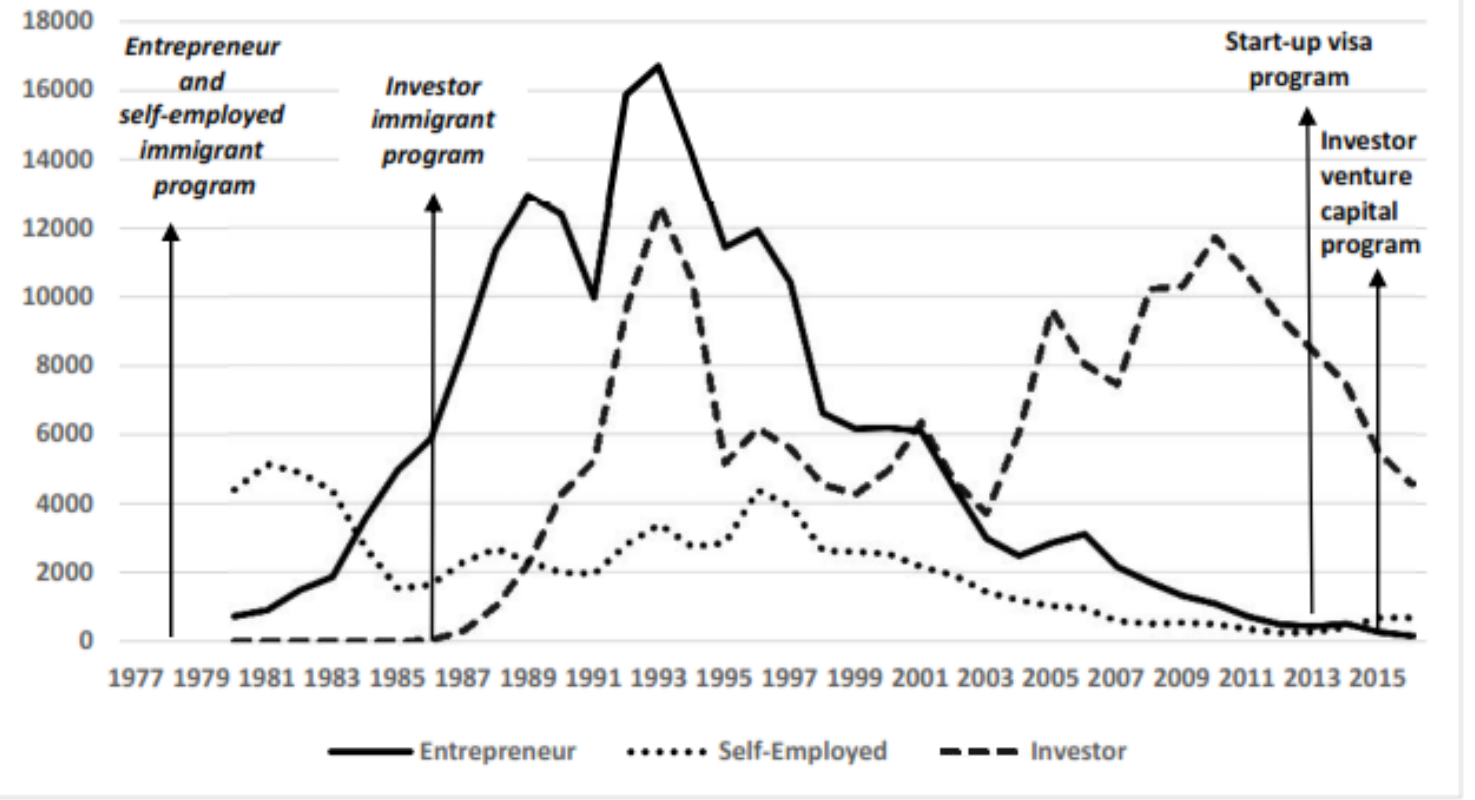

Source: Immigration, Refugee and Citizenship Canada (IRCC), 2014 and 2017c

Table 3 lists the top 20 countries/regions of origin (by place of birth) for the 20 year period 1980-1999, from which as high as 85 percent of Canada's business immigrants originated. Seven of them were in East/Southeast/South Asia; another seven (including Egypt) in the Middle East; and five in Europe. The largest was the tiny territory of Hong Kong, sending 76,000 business immigrants to Canada, accounting for one quarter of all the business immigrants to Canada in that period. This was the result of the large exodus of investors and entrepreneurs from Hong Kong amid concerns about the uncertainty surrounding the handover of Hong Kong to China in 1997 (as mentioned on page 5). The other places of origin that sent more than 10,000 were Taiwan, mainland China, and Korea. Coincidently, that was also a time period when small-scale ethnic businesses mushroomed in the major Canadian cities. For example, most Chinese shopping centers in metropolitan Toronto and Vancouver were built in the mid and late 1990s, and the retail units were quickly filled with retail shops and restaurants, as many immigrants purchased a store unit and created a job for themselves to meet the immigration criteria either as an entrepreneur or a self-employed individual (Wang, 1999). That was also the start of the suburbanization of ethnic businesses in the major Canadian cities.

In the following 17 years (2000-2016), the top 20 places of origin are similar (with only four of them being different), still accounting for 88 percent of Canada's business immigrants; but their ranking has been altered significantly (Table 4). Mainland China replaced Hong Kong to become the largest source country, which alone sent 80,000 , accounting for 43 percent of Canada's total business immigrants in the new millennium. Ninety-one percent of the business immigrants from China were investors, as the higher investment threshold implemented in the 2010-2014 period highly favoured the Chinese parvenus, but filtered out many applicants from 
Table 3 Top 20 Places of Birth for Business Immigrants, 1980-1999

\begin{tabular}{|c|c|c|c|c|c|c|c|}
\hline Rank & Places of birth & World region & Entrepreneur & Self-Employed & Investor & $\begin{array}{l}\text { Total business } \\
\text { immigrants }\end{array}$ & $\begin{array}{l}\% \text { of all business } \\
\text { immigrants to } \\
\text { Canada }\end{array}$ \\
\hline 1 & Hong Kong & Asia & 47,595 & 6,330 & 22,066 & 75,991 & 25.3 \\
\hline 2 & Taiwan & Asia & 16,576 & 3,994 & 24,191 & 44,761 & 14.9 \\
\hline 3 & China & Asia & 16,416 & 2,873 & 10,948 & 30,237 & 10.1 \\
\hline 4 & Korea & Asia & 18,603 & 1,396 & 3,491 & 23,490 & 7.8 \\
\hline 5 & Germany & Europe & 4,030 & 4,691 & 480 & 9,201 & 3.1 \\
\hline 6 & Iran & Asia & 5,252 & 1,988 & 748 & 7,988 & 2.7 \\
\hline 7 & Lebanon & Asia & 4,603 & 1,817 & 177 & 6,597 & 2.2 \\
\hline 8 & U.S.A. & North America & 2,161 & 3,372 & 478 & 6,011 & 2.0 \\
\hline 9 & India & Asia & 4,265 & 1,165 & 487 & 5,917 & 2.0 \\
\hline 10 & England & Europe & 2,197 & 3,508 & 193 & 5,898 & 2.0 \\
\hline 11 & Netherlands & Europe & 640 & 5,004 & 23 & 5,667 & 1.9 \\
\hline 12 & Pakistan & Asia & 3,938 & 573 & 456 & 4,967 & 1.7 \\
\hline 13 & Philippines & Asia & 2,336 & 786 & 1,442 & 4,564 & 1.5 \\
\hline 14 & Kuwait & Asia & 3,719 & 439 & 327 & 4,485 & 1.5 \\
\hline 15 & Switzerland & Europe & 863 & 3,544 & 68 & 4,475 & 1.5 \\
\hline 16 & Syria & Asia & 2,733 & 1,075 & 273 & 4,081 & 1.4 \\
\hline 17 & Egypt & Africa & 2,576 & 822 & 336 & 3,734 & 1.2 \\
\hline 18 & France & Europe & 1,383 & 1,804 & 40 & 3,227 & 1.1 \\
\hline 19 & Israel & Asia & 1,672 & 903 & 139 & 2,714 & 0.9 \\
\hline 20 & Saudi Arabia & Asia & 1,810 & 289 & 405 & 2,504 & 0.8 \\
\hline \multicolumn{3}{|c|}{ Total from all countries } & 167,734 & 61,200 & 71,655 & 300,589 & \\
\hline
\end{tabular}

Source: Immigration, Refugee and Citizenship Canada (IRCC), 2014 and 2017c 
Table 4 Top 20 Places of Birth for Business Immigrants, 2000-2016

\section{S. Wang \& R. Hii}

\begin{tabular}{|c|c|c|c|c|c|c|c|c|}
\hline Rank & Place of birth & World region & Entrepreneur & $\begin{array}{c}\text { Self- } \\
\text { employed }\end{array}$ & Investor & Start-up & $\begin{array}{l}\text { Total business } \\
\text { immigrants }\end{array}$ & $\begin{array}{c}\% \text { of all business } \\
\text { immigrants to } \\
\text { Canada }\end{array}$ \\
\hline 1 & China & Asia & 5,230 & 1,432 & 72,946 & 36 & 79,644 & 43.3 \\
\hline 2 & Korea & Asia & 6,519 & 891 & 9,546 & 0 & 16,956 & 9.2 \\
\hline 3 & Iran & Asia & 4,444 & 875 & 9,097 & 14 & 14,430 & 7.8 \\
\hline 4 & Taiwan & Asia & 1,678 & 1,123 & 9,136 & 0 & 11,937 & 6.5 \\
\hline 5 & Pakistan & Asia & 2,825 & 294 & 3,316 & 0 & 6,435 & 3.5 \\
\hline 6 & India & Asia & 2,751 & 798 & 2,066 & 51 & 5,666 & 3.1 \\
\hline 7 & England & Europe & 802 & 1,107 & 738 & 16 & 2,663 & 1.4 \\
\hline 8 & Egypt & Africa & 606 & 141 & 1,897 & 8 & 2,652 & 1.4 \\
\hline 9 & U.S.A. & North America & 659 & 964 & 1,018 & 5 & 2,646 & 1.4 \\
\hline 10 & Netherlands & Europe & 250 & 1,878 & 174 & 0 & 2,302 & 1.3 \\
\hline 11 & Bangladesh & Asia & 479 & 52 & 1,582 & 0 & 2,113 & 1.1 \\
\hline 12 & Turkey & Asia & 134 & 105 & 1,774 & 3 & 2,016 & 1.1 \\
\hline 13 & UAE & Asia & 620 & 56 & 1,216 & 4 & 1,896 & 1.0 \\
\hline 14 & Lebanon & Asia & 675 & 327 & 846 & 0 & 1,848 & 1.0 \\
\hline 15 & $\mathrm{HK}$ & Asia & 408 & 66 & 1,238 & 3 & 1,715 & 0.9 \\
\hline 16 & Saudi Arabia & Asia & 348 & 23 & 1,327 & 0 & 1,698 & 0.9 \\
\hline 17 & France & Europe & 558 & 880 & 215 & 0 & 1,653 & 0.9 \\
\hline 18 & German & Europe & 527 & 672 & 261 & 0 & 1,460 & 0.8 \\
\hline 19 & Syria & Asia & 472 & 160 & 668 & 0 & 1,300 & 0.7 \\
\hline 20 & Iraq & Asia & 283 & 41 & 916 & 0 & 1,240 & 0.7 \\
\hline \multicolumn{3}{|c|}{ Total from all countries } & 37,012 & 16,096 & 130,617 & 209 & 183,934 & \\
\hline
\end{tabular}

Source: Immigration, Refugee and Citizenship Canada (IRCC), 2014 and 2017c 
other countries. The other places that sent more than 10,000 business immigrants to Canada were Korea, Iran and Taiwan, but their numbers were much smaller than in the previous two decades. Hong Kong descended to the $15^{\text {th }}$ place, sending only 1,700 (compared with 76,000 in the previous two decades).

Since the introduction of the Start-Up Visa program in 2014, only 209 immigrants of this category successfully passed screening and were issued a visa. Of these, 51 were from India, 36 from China, 16 from the UK, and 14 from Iran. Due to its recency, the effectiveness of this new program remains to be seen, but a precipitous drop has already been noted. The landing records also show that by the end of 2016, no investors were issued a landing paper through the Venture Capital Program (with only two visas issued in the first half of 2017).

The business immigrants did seem to possess less human capital than the skilled workers - the largest category of economic immigrants. As Table 5 shows, only 12 percent of the business immigrants, admitted to Canada between 1980 and 1999 under the former programs, had a university degree or a post graduate degree; and only 44 percent were able to demonstrate official language ability at the time of immigration. These were much lower than the skilled workers (at $31.2 \%$ and $76.5 \%$, respectively).

Table 5 Business immigrants by education and Canadian official language ability, 1980-1999 (in percentage)

\begin{tabular}{|l|c|c|c|c|c|}
\hline & Entrepreneur & Self-employed & Investor & $\begin{array}{c}\text { All business } \\
\text { immigrants }\end{array}$ & $\begin{array}{c}\text { Skilled } \\
\text { worker }\end{array}$ \\
\hline Education qualification & $\%$ & $\%$ & $\%$ & $\%$ & $\%$ \\
\hline Less than university degree & 88.5 & 88.4 & 88.8 & 88.5 & 68.8 \\
\hline University degree or higher & 11.6 & 11.6 & 11.3 & 11.5 & 31.2 \\
\hline Bachelor & 10.1 & 9.2 & 9.8 & 9.9 & 21.8 \\
\hline Master & 1.2 & 1.8 & 1.2 & 1.3 & 7 \\
\hline Doctorate & 0.3 & 0.6 & 0.3 & 0.3 & 2.4 \\
\hline Total & 100.0 & 100.0 & 100.0 & 100.0 & 100.0 \\
\hline & & & & & \\
\hline Official language ability & & & & & \\
\hline English & 38.3 & 48.2 & 28.9 & 38.1 & 62.2 \\
\hline French & 2.3 & 7.2 & 0.5 & 2.9 & 6.8 \\
\hline Bilingual & 3.2 & 5.6 & 0.7 & 3.1 & 7.5 \\
\hline None & 56.2 & 39.1 & 69.9 & 56.0 & 23.4 \\
\hline Total & 100.0 & 100.0 & 100.0 & 100.0 & 100.0 \\
\hline
\end{tabular}

Source: Immigration, Refugee and Citizenship Canada (IRCC), 2014 and 2017c

Those who were admitted between 2000 and 2016, on average, have higher levels of education (19.4\%) and official language ability (40.3\%), as shown in Table 6; but these are still significantly lower than the skilled workers (48.5\% and $62.7 \%$ respectively). These data indeed provided grounds for the federal government to introduce drastic changes to the former business immigrant programs. Admitted under the new programs, the small number of Start-Up Visa immigrants show a much higher level of human capital: 52 percent have a university degree or post graduate degree, and 90 percent meet the official language requirement: both are higher than the skilled workers (48.5\% and $82 \%) .{ }^{3}$

\footnotetext{
${ }^{3}$ It should be pointed out that the business immigrants admitted through the Quebec program are not included in the IRCC maintained landing records, and those admitted through the PNPs are aggregated into one large category of "provincial nominees", making it impossible to count how many of them were business immigrants.
} 
Table 6 Business immigrants by education and Canadian official language ability, 2000-2016 (in percentage)

\begin{tabular}{|l|c|c|c|c|c|c|}
\hline & Entrepreneur & $\begin{array}{c}\text { Self- } \\
\text { employed }\end{array}$ & Investor & Start-ups & $\begin{array}{c}\text { All business } \\
\text { immigrants }\end{array}$ & $\begin{array}{c}\text { Skilled } \\
\text { worker }\end{array}$ \\
\hline Education qualification & & & & & & \\
\hline Less than university degree & 82.0 & 78.6 & 80.4 & 47.9 & 80.5 & 48.2 \\
\hline University degree or higher & 18.1 & 21.3 & 19.5 & 52.1 & 19.4 & 48.5 \\
\hline Bachelor & 14.9 & 15.1 & 14.7 & 30.1 & 14.8 & 28.0 \\
\hline Master & 2.7 & 5.1 & 4.0 & 19.1 & 3.8 & 17.6 \\
\hline Doctorate & 0.5 & 1.1 & 0.8 & 2.9 & 0.8 & 2.9 \\
\hline Missing & 0.0 & 0.2 & 0.1 & 0.0 & 0.1 & 3.2 \\
\hline Total & 100.0 & 100.0 & 100.0 & 100.0 & 100.0 & 100.0 \\
\hline & & & & & & \\
\hline Official language ability & & & & & & \\
\hline English & 39.7 & 47.7 & 32.5 & 90.9 & 35.3 & 53.8 \\
\hline French & 2.9 & 6.4 & 1.1 & 0.5 & 1.9 & 8.9 \\
\hline Bilingual & 3.4 & 8.1 & 2.4 & 2.4 & 3.1 & 19.0 \\
\hline None & 54.0 & 37.7 & 64.0 & 6.2 & 59.6 & 18.3 \\
\hline Total & 100.0 & 100.0 & 100.0 & 100.0 & 100.0 & 100.0 \\
\hline
\end{tabular}

Source: Immigration, Refugee and Citizenship Canada (IRCC), 2014 and 2017c

Immigration policy adjustments are not only prompted by the changes in the receiving country's economic conditions, but also influenced by the political ideology of the federal governing party. In Canada, drastic changes were made when the PCP was in power (2006-2015). In immigration policy making, the PCP seemed to have taken a utilitarian approach, believing in immediate contributions to be made by immigrants shortly after arrival. For the same reason, the PCP expanded the admission of skilled workers by introducing the Express Entry class of immigrants, and tightened the admission of family members (particularly parents). At the same time, it introduced the Super Visa - a 10year, multi-entry visa designed mainly for family reunification without immigration.

\section{Implications for Future Development of Ethnic Business in Canada}

Periodic policy adjustments are necessary, but eliminating the entrepreneur and investor programs entirely may be too drastic. With a slow recovery from the 2008 recession among the Western economies, competition for business talent and global capital has intensified. The much raised entry bar in the Start-Up Visa and the Venture Capital programs may deter many potential business immigrants from applying to Canada, and turn them to competing countries, such as the U.S., Australia and UK.

In the U.S., its EB-5 Visa Program, created in 1990, provides an avenue for eligible immigrant investors to become permanent residents by investing US $\$ 1$ million to finance a business that will employ at least 10 American workers (U.S. Citizenship and Immigration Services, 2007). If an immigrant investor commits to investing in a rural area or in an area with high unemployment, the investment threshold is lowered to $\$ 500,000$, with no minimum net worth requirement. The investment will be returned in full within 4 to 6 years. This program has proven to be very popular, and it is much more "affordable" 
than Canada's new Venture Capital program. Most investors attracted by the EB- 5 Visa Program - about 80 percent - were from five places of origin: China, South Korea, Taiwan, UK, and Hong Kong - all also the major origins of Canada's business immigrants. After Canada cancelled its investor program, the U.S. became the default leader in this investment market (Dyck, 2015).

Australia accepts business immigrants in three streams: Business Innovation, Business Investor, and Business Talent (Migration Expert Australia, 2017). The Business Innovation Stream visa is designed for successful business owners who are required to demonstrate a successful business career with significant turnover and a commitment to owning a business in Australia. The Business Investor Stream visa allows successful business people to invest in a new or existing business in Australia. Applicants are required to demonstrate a successful record of investment or business activity in a qualifying business or investment. In addition to demonstrating that they have sufficient assets to settle in Australia, they must make a significant designated investment in Australia prior to the visa being granted, which will be held for four years. This is similar to the abandoned Canadian Investor Immigrant Program. Unlike the Canadian programs, both the Business Innovation visa and the Business Investor visa issued by the Australian government are provisional: they are issued initially for four years, and can be extended or turned to permanent thereafter, based on whether the terms and conditions of immigration are met. The Business Talent visa is a permanent visa granted to the highest calibre of business people, who are able to demonstrate that they have a successful business career and that their main business generated a minimum turnover of AUD\$3 million for at least two of the preceding four years.

Similar to Australia, UK also accepts business immigrants in three streams: entrepreneur, investor, and innovator (UK Immigration, 2017). Successful entrepreneur immigrants are required to invest $£ 200,000$ in a new UK business, create full time employment for at least 2 EEA nationals (who live and work in the UK), work solely in the business they invested, and have sufficient funds to accommodate themselves until the business becomes profitable. To qualify for an investor immigrant, one must have at least $£ 1$ million to invest in the UK, of which at least $£ 750,000$ must be invested in unit trusts (the UK term for mutual funds) or private companies; the remaining $£ 250,000$ may be invested in other industry/business sectors, all for five years with interest paid to the investors (Dyck, 2015). These immigrants must be "active investors" (as opposed to being "passive investors" in the U.S. and Canada), meaning that they may not take employment beyond managing their own invested business, and they must make the UK their main home and spend at least 50 percent of their time in the UK (as opposed to being "astronaut" immigrants). The business innovators, also known as "exceptional talent", are equivalent to Australia's Business Talent and Canada's Start-Up categories. This category is reserved for those applicants who have an excellent business idea that will bring very considerable economic benefits to the UK, and is tailored to those in the new industries of information technology and telecommunication sectors. The successful innovators are also expected to raise the needed capital by themselves without financial support from the UK government.

There are three major differences between the existing business programs of the U.S., Australia and UK and Canada's new and abolished business immigrant programs. First, the threshold requirements for investors by the three competing countries are all lower than Canada's Venture Capital Program; they are therefore more "affordable". Second, the investment terms in these three countries are shorter than that of Canada's Venture Capital Program. Third, the U.S., Australia, and UK all issue provisional visas initially, and extend the visas only if the terms of immigration are fulfilled within the specified time period, whereas Canada grants permanent residence status at the time of approving the application.

By eliminating the decades-long entrepreneur and investor programs and 
replacing them with the new Start-Up Visa and Venture Capital programs, Canada is poised to lose many resourceful business immigrants to the competing countries, thus affecting the future growth of ethnic businesses. If the two pilot programs are to continue and expand without restoring the previous entrepreneur and investor programs, they would lead to significant changes to the number and structure of ethnic businesses in Canada. The number of business immigrants to Canada will be reduced substantially, as the landing data have shown (see Figure 1 and Table 2). Even if the two pilot programs are to attract a good number of talented and ultra-wealthy immigrants, the new types of businesses run and financed by these immigrants will not be limited to creating jobs for immigrants and to serving co-ethnic consumers only. Instead, they will likely create highquality and high-paid jobs in high-tech and manufacturing industries. Ethnic retail and commercial activities will still exist, but growth will stagnate. These commercial activities will also be less facilitated by formal immigration programs, as was the case in the 1980s and the 1990s. This has already been happening in Metropolitan Toronto, where only a very small number of new Chinese shopping malls were developed and marketed after 2010. Some of them have never been filled up, with many vacancies; others have either not been completed yet or been on hold indefinitely. For example, Splendid China Tower, which was opened for business in 2007, still has a vacancy rate of 22 percent (as reported in Zhuang and Chen, 2017); King Square Shopping Center, which took 8 years to be built, has yet to open for business (as of February 2019).

The PCP government was replaced by the Liberals during the 2015 federal election. The Liberal Party, which quickly renamed the ministry of Citizenship and Immigration Canada (CIC) to Immigration, Refugees and Citizenship Canada (IRCC) to signal program reform, is long known for taking a more humanitarian than utilitarian approach in immigration policy making. When asked if the Liberal government would reverse the pilot business immigrant programs, the (then) new immigration minister, John McCullum, cautiously said that "We are reviewing options to determine the next steps, but no decisions have been made. ... We want to ensure our immigration system grows the economy and also focuses on family unifications" (Mas, 2016). It is a long-held belief of the Liberals that Canada should focus on growing immigrant families, because in a long run, immigrant children growing up in Canada will be much better integrated in the Canadian society in general than the adult immigrants, and therefore be more able to contribute to Canada both economically and culturally.

\section{Conclusions}

Immigration policy, especially business immigration policy, is an important influencing and facilitating factor for contemporary ethnic businesses development, but has received inadequate attention in the existing literature. In importance, business immigration policies not only regulate the inflows of international entrepreneurs and investors (by quota), but also channel the associated resources and capital into different economic sectors (by issuing different types of business immigrant visa). If not executed properly, such policies may incur inadvertent economic consequences.

While most immigrant-receiving countries reply on immigrants to sustain population growth and economic expansion, these countries also face the challenge of creating enough jobs to utilize their talents and potential. For this reason, including a healthy number of business immigrants in the total immigrant intake is a partial solution, because most (if not all) of the business immigrants would create a job for themselves or for other immigrants either directly (by establishing a business) or indirectly (with the capital they bring with them). 
Admitting 300,000 immigrants each year to meet its immigration goal, Canada does indeed need an immigration system that is resilient to the shocks of economic externalities. As this study illustrates, the Canadian business immigration policies have undergone thoughtful changes in the new millennium, with the intention to enhance the benefits for Canada in the increasingly competitive global economy. However, not all the impacts so far appear to be beneficial. The cancellation of the Entrepreneur Immigrant Program and the Investor Immigrant Program has substantially reduced the supply of immigrant entrepreneurs and overseas capital. If the total intake of immigrants increases further (to $1 \%$ of the national population), there will be more pressure for the country to create more jobs to settle the newcomers. Yet, the newly introduced Star-Up Visa Program and Investor Venture Capital Program do not seem to be able to attract enough new foreign entrepreneurs who both have innovative ideas and will actively pursue business ventures that are able to create better jobs and compete globally, because of the excessively high selection criteria and the limited pool of qualified candidates. As a result, the much raised entry bar in the Start-Up Visa and Venture Capital programs may well deter potential business immigrants from choosing Canada as their preferred destination, and turn them to the competing countries. Furthermore, the small number of talented and ultra-wealthy business immigrants who do choose Canada will most likely to be channeled into manufacturing and high-tech industry. While this is an intended policy outcome, the future growth of ethnic retailing and commercial services may not be sustainable.

It is true that not all ethnic businesses are initiated by immigrants who came to Canada as entrepreneurs, self-employed or investors. Some ventured into ethnic businesses after they were admitted to Canada as a skilled worker and failed in seeking rewarding employment, as explained in the Blocked Mobility Thesis. However, these business owners are much less likely to have the same business acumen and resources than the entrepreneur and self-employed immigrants. This also defeats the purpose of admitting them to Canada in the first place, as these skilled worker-turned small business operators are not utilizing their skills, on the basis of which they were selected to immigrate to Canada.

Business immigration reform is necessary, but policy adjustments need a wide range of consultation among all stakeholders, including all levels of government, business and industry organizations, immigration communities, and the Canadian society at large, as suggested by the actor-based theories. In our view, the previous immigrant entrepreneur and investor programs need not to be abandoned entirely. Instead, they can be retooled and be combined with the good elements in the Start-Up and Venture Capital programs. For example, investment can still be placed in a venture capital fund to finance Canadian-based start-up companies, but the minimum amount can be lowered to $\$ 1$ million and the investment period can be shortened to 7-10 years. This would lower the investment risks for the investors, and make Canada a more attractive and more competitive destination for many entry-level and mid-level investors. After all, the number of ultra-rich investors is small, and they may not necessarily want to invest in Canada, whose economy and market is much smaller than that of the U.S.

Raising requirements for education qualifications and Canadian language ability may benefit both Canada and the business immigrant themselves. As "passive" investors, the investor immigrants are not involved in running and managing the business they invest in. Without appropriate education qualification and official language ability, they may not be able to find a suitable job to support themselves and their families if their at-risk investment in the venture capital fund does not generate enough regular returns. For some entrepreneurs, their businesses, after going into operation, may fail for various reasons (e.g., due to changing market conditions). If this happens, the entrepreneurs without proper education and language skills may also have difficulty entering the general labour market, as evidenced by the higher-than-average unemployment insurance usage rate among the investor immigrants, documented in Wang and Lo's study (2000). 
What is needed the most is a new monitoring system with more effective compliance mechanisms to safeguard the interest of both Canada and the business immigrants. The Quebec Immigrant Investor Program with multi layers of due diligence mechanisms has been claimed to be very successful in meeting its objectives. Issuing conditional permanent residence status or a temporary visa to business immigrants may be part of the new mechanisms, as done in other countries, though its execution may be difficult. (For example, terminating a visa after an immigrant and his/her family have lived in Canada for several years could lead to legal action, and the resulting legal process could be long and costly for the government of Canada.) P.E.I., after closing its business immigration streams in 2018, still welcomes entrepreneurs and investors, but issues them a work permit for the "probation" period, instead of giving them permanent resident status at the time of approving their business plans and investment commitment.

In sum, business immigration policy reform should focus on strengthening the monitoring mechanism and enforcing fulfillment of the terms and conditions of immigration. Future growth of ethnic businesses will, to a large degree, depend on the openness of the immigration policies. Too restrictive policies will undoubtedly reduce a country's attractiveness and make the country less competitive in attracting business talents. This is true not only for Canada but for other immigrant receiving countries as well. 


\section{References}

Carman, T. and O'Neil, P. 2014. Ottawa scraps investor immigrant program. Vancouver Sun. retrieved from http://www.vancouversun.com/news/Ottawa+scraps+investor+immigrant+progra m/9496380/story.html

Citizenship and Immigration Canada (CIC). 2010. Backgrounders - Changes to the Federal Immigrant Investor Program to bring Canada more resources to fund economic development and job creation initiatives. Retrieved from: http://www.cic.gc.ca/english/department/media/backgrounders/2010/2010-0626b.asp

Citizenship and Immigration Canada (CIC). 2011. Evaluation of Ministerial Instructions (Implementation). Retrieved from: http://www.cic.gc.ca/english/pdf/researchstats/min-instruct.pdf

Citizenship and Immigration Canada (CIC). 2014a. Evaluation of the Federal Business Immigration Program. Retrieved from: http://www.cic.gc.ca/english/pdf/pub/e22013 FBIP.pdf

Citizenship and Immigration Canada (CIC). 2014b. Annual Report to Parliament on Immigration. Retrieved from: http://www.cic.gc.ca/english/pdf/pub/annual-report2014.pdf

Citizenship and Immigration Canada (CIC). 2014c. Federal Entrepreneurs program. Retrieved from: http://www.cic.gc.ca/english/immigrate/business/entrepreneurs/index.asp

Citizenship and Immigration Canada (CIC). 2014d. Self-employed people. Retrieved from http://www.cic.gc.ca/english/immigrate/business/self-employed/index.asp

Citizenship and Immigration Canada (CIC). 2014e. Investors. Retrieved from: http://www.cic.gc.ca/english/immigrate/business/investors/index.asp

Citizenship and Immigration Canada (CIC). 2015. Immigrant Investor Venture Capital Program. Retrieved from: http://www.cic.gc.ca/english/immigrate/business/iivc/.

DeRosa, J. D. 1995. The Immigrant Investor Program: Cleaning Up Canada's Act. Retrieved from: http://scholarlycommons.law.case.edu/cgi/viewcontent.cgi ?article=1570\&context= iil.

Dyck, D. 2015. Canada losing lucrative immigrant investors: the Harper government's new program is a charade. Financial Post, February 9, 2015. Retrieved from http://business.financialpost.com/opinion/canada-losing-lucrative-immigrantinvestors/wcm/002e94da-f6d1-44a0-8bf7-d73ad6da4c4d

Freeman, G. P. 1995. Modes of immigration politics in liberal democratic states. International Migration Review 29 (4): 881-902.

Global Immigration Law Firm. 2018. PEI to close business immigration streams. 
CanadIm. https://www.canadim.com/pei-business-changes/

Government of Canada (GOC). 2014. Budget 2014: Chapter 3.1. - Connecting Canadians with Available Jobs. Retrieved from: http://www.budget.gc.ca/2014/docs/plan/ch3-1-eng.html

Green, A. G. and Green, D. 2004. The goals of Canada's immigration policy: a historical perspective. Canadian Journal of Urban Research, 13(1), 102-139.

Harrison, T. 1996. Class, Citizenship, and Global Migration: The Case of the Canadian Business Immigration Program, 1978-1992. Canadian Public Policy, 22(1), 7-23.

Immigration.ca. 2017. Despite years of warnings, Canada's business immigration programs plagued by fraud. Retrieved from http://www.immigration.ca/despiteyears-warnings-canadas-business-immigration-programs-plagued-fraud/

Immigration, Refugee and Citizenship Canada (IRCC), 2014. Landed Immigrant Database 1980-1999. Ottawa.

Immigration, Refugee and Citizenship Canada (IRCC). 2016. Evaluation of the Start-Up Visa SUV) pilot. Retrieved from: http://www.cic.gc.ca/english/pdf/pub/E5-2015SUV-ENG.pdf

Immigration, Refugee and Citizenship Canada (IRCC). 2017a. Ministerial Instructions. Retrieved from: http://www.cic.gc.ca/english/department/mi/index.asp.

Immigration, Refugee and Citizenship Canada (IRCC). 2017b. Start-up Visa Program. Retrieved from: http://www.cic.gc.ca/english/immigrate/business/startup/index.asp.

Immigration, Refugee and Citizenship Canada (IRCC), 2017c. Landed Immigrant Database, 2000-2016. Ottawa.

Kloosterman, R. 2006. Mixed embeddedness as a conceptual framework for exploring immigrant entrepreneurship. Eurex Lecture No. 8. (https://www.researchgate.net/publication/228544072 Mixed Embeddedness as a Conceptual Framework for Exploring Immigrant Entrepreneurship)

Kloosterman, R., van der Leun, J. and Rath, J. 1999. Mixed embeddedness: (in)formal economic activities and immigrant business in the Netherlands. Journal of Urban and Regional Research, 23 (2): 253-267.

Knowles, V. 2016. Strangers at Our Gates: Canadian Immigration and Immigration Policy, 1540-2015. Toronto: Dundurn Press.

Ley, D. 2003. Seeking homo economicus: the Canadian state and the strange story of the business immigration program. Annals of the Association of American Geographers, 93(2): 426-441.

Li, P. S. 1993. Chinese investment and business in Canada: ethnic entrepreneurship reconsidered. Pacific Affairs, 66(2): 219-243. 
Li, P. S. 2003. Destination Canada: Immigration Debates and Issues. Oxford: Don Mills.

Li, P. S. 2005. The rise and fall of Chinese immigration to Canada: newcomers from Hong Kong Special Administrative Region of China and Mainland China, 19802000. International Migration, 43(3): 9-34.

Macklin, A. 2010. Freeing migration from the state: Michael Trebilcock's model for immigration policy. University of Toronto Law Journal, 60(2): 315-348.

Mas, S. 2016. Millionaire immigrant investor program lures only 7 instead of 60 . $C B C$ News. Retrieved from: http://www.cbc.ca/news/politics/immigration-investor-pilotprogram-1.3331204.

Migration Experts- Australia. 2017. Business Visas. Retrieved from https://www.migrationexpert.com.au/migration expert australia/

Milner, H. V. and Tingley, D. 2011. The economic and political influences on different dimensions of United States immigration policy. Social Science Research Network (SSRN) Electronic Journal. (DOI: 10.2139/ssrn.2182086). https://scholar.princeton.edu/sites/default/files/hvmilner/files/the economic and political influences on different dimensions of united states immigration polic y.pdf. (Accessed on September 1, 2018)

Murray, D. 2005. Business immigration class a big failure. The Vancouver Sun, June 21. Retrieved from http://immigrationwatchcanada.org/2005/06/21/businessimmigration-class-a-big-failure/

Natter, K. 2018. Rethinking immigration policy theory beyond 'Western liberal democracies'. Comparative Migration Studies 6(1). (Published online, no page number.) https://link-springercom.ezproxy.lib.ryerson.ca/article/10.1186\%2Fs40878-018-0071-9 (accessed on September 1, 2018)

Pagtakhan, R. R. 2012. How to fix business immigration. Winnipeg Free Press. Retrieved from https://www.winnipegfreepress.com/opinion/analysis/how-to-fixbusiness-immigration-182324601.html

Reitz, J. G. 2004. Canada: immigration and nation-building in the transition to a knowledge economy. In W.A. Cornelius, T. Tsuda, P.L. Martin and J.F. Hollifield's (Eds.) Controlling Immigration: A Global Perspective (Second Edition). Stanford: Stanford University Press. pp. 97-133.

Seward, S. B. 1987. The Relationship between Immigration and the Canadian Economy. Ottawa: Institute for Research on Public Polio.

UK Immigration. 2017. Business Visas. Retrieved from http://www.ukimmigration.com/entrepreneur/

US Citizenship and Immigration Services. 2017. EB-5 Immigrant Investor Program. Retrieved from $\mathrm{Https}$ :/Www.Uscis.Gov/Eb-5

Wong, L. L. 1993. Immigration as capital accumulation: the impact of business immigration to Canada. International Migration, 31(1): 171-190. 
Wang, S. 1999. Chinese commercial activity in the Toronto CMA: new development patterns and impacts. The Canadian Geographer, 43 (1): 19-35.

Wang, S. and Lo, L. 2000. Economic impacts of immigrants in the Toronto CMA: a taxbenefit analysis. Journal of International Migration and Integration, 1 (3): 273-303.

Yarr, K. 2018. Citing concerns, P.E.I. shutting down PNP's immigrant entrepreneur program. https://www.cbc.ca/news/canada/prince-edward-island/pei-pnpentrepreneur-program-closed-1.4820072

Zhuang, Z. C. and Chen, A. X. 2017. The role of ethnic retailing in retrofitting suburbia: sase studies from Toronto, Canada. Journal of Urbanism: International Research on Place-Making and Urban Sustainability. 10 (3): 275-295.

Zogata-Kusz, Agnieszka. 2012. Theoretical perspectives on immigration policy and politics. Contemporary European Studies, 1: 5-21. 